\title{
The Canadian Prairie Plant Thermopsis Rhombifolia Contains Luteolin, a Flavone that Inhibits Cyclin Dependent Kinase 9 and Arrest Cells in the G1-Phase of the Cell Cycle
}

Jan M. Tuescher, $\mathrm{MSc}^{1}$, Deserae Tailfeathers, $\mathrm{BSc}^{1}$, Sophie M. Kernéis, $\mathrm{PHD}^{2}$, Blandine Baratte, $\mathrm{MSc}^{3,4}$, Sandrine Ruchaud, $\mathrm{PHD}^{3,4}$, Stéphane Bach, $\mathrm{PHD}^{3,4}$, Muriel Batut, $\mathrm{MSC}^{5}$, Isabelle Pouny, $\mathrm{PHD}^{5}$, François Sautel, $\mathrm{PHD}^{5}$, Roy M. Golsteyn, $\mathrm{PHD}^{1 *}$

${ }^{1}$ Natural Product Laboratory, Department of Biological Sciences, 4401 University Dr, University of Lethbridge, Lethbridge, AB, Canada T1K $3 \mathrm{M} 4$

${ }^{2}$ Microbiology Research Group, 3000 College Dr S, Lethbridge College, Lethbridge, AB Canada T1K 1L6

${ }^{3}$ Sorbonne Université, CNRS, UMR 8227, Integrative Biology of Marine Models Laboratory (LBI2M), Station Biologique de Roscoff, CS 90074, 29688 Roscoff Cedex, France

${ }^{4}$ Sorbonne Université, CNRS, FR 2424, Plateforme de criblage KISSf (Kinase Inhibitor Specialized Screening facility), Station Biologique de Roscoff, CS 90074, 29688 Roscoff Cedex, France

${ }^{5}$ Pierre Fabre Laboratories, USR 3388 CNRS-Pierre Fabre, 3 avenue Hubert Curien, BP 13562, Toulouse, Cedex 1, France

* Corresponding Author: roy.golsteyn@uleth.ca

\begin{abstract}
INTRODUCTION: Plant species within the prairie ecological zone of Canada are a source of natural products with important bio-activities. Investigation of these plants and the secondary metabolites that they produce will provide insight into their biology, and identify sources of natural products that may become new medicines or scientific tools.

METHODS: We investigated a G1 phase arrest activity in extracts from the prairie plant, Thermopsis rhombifolia (Buffalo bean) by biology-guided fractionation and isolated luteolin. Cell based assays and CETSA were used to identify a cyclin-dependent kinase 9 inhibitory activity.
\end{abstract}

RESULTS AND DISCUSSION: Luteolin treated cells showed decreased phosphorylation of the carboxy terminal domain of RNA polymerase II, and low levels of Mcl-1. Plant extracts or luteolin inhibited Cdk9 (cyclin dependent kinase) in tests in vitro, stabilized Cdk9 as determined by the cellular thermal shift assay (CETSA), and arrested cells in the G1 phase of the cell cycle.

CONCLUSIONS: Luteolin joins an increasing number of flavonoid inhibitors that make convenient cell biology tools and contribute to our understanding of natural product biology in plants.

KEYWORDS: cell cycle; CETSA (cellular thermal shift assay); kinase inhibitor; natural products

\section{Introduction}

Plant species of the Canadian prairie ecological zone have evolved under a competition regime comprised of grazing herbivores and a short reproductive period limited by climatic conditions. To compete successfully under this regime, some plants synthesize secondary metabolites that affect mammalian physiology [1]. Both anecdotal and scientific evidence demonstrate that prairie plants produce chemicals that are toxic to grazing herbivores or humans [2]. Only in a handful of cases, however, has the toxicity been investigated to the level of the identification of the chemical and its biological target. It is noteworthy that natural products are the major source of modern medicines, and that these chemicals are invaluable tools with which to investigate cellular pathways [3]. 
Phenotypic assays are an experimental approach in which extracts or chemicals are screened in cells or organisms for effects upon broad biological phenomena such as proliferation, cell death, or morphology, amongst others [4]. This approach is in contrast to that of targeted assays in which a specific molecular target, such as a protein kinase, is screened. The two approaches are complementary, although phenotypic assays have been recognized as the more successful of the two in identifying biological effects of inhibitors [5]. Some of the reasons for the success of phenotypic assays include that live biological systems (cells or organisms) capture more of features required for measuring meaningful inhibition, such as multiple competing targets, and structural differences of a protein in the native cellular environment. Once an effect of a chemical has been observed, one can use cell biology data to evaluate results from phenotypic experiments. Finally, hypotheses that arise from phenotypic assays can be tested by targeted approaches, such as the cellular thermal shift assay (CETSA).

We have previously reported that extracts prepared from the prairie plant species, T. rhombifolia, were toxic to human cells and induced a cell cycle arrest [10]. Here, we identified that extracts specifically inhibited Cdk9 in biochemical assays and decreased levels of the anti-apoptotic protein, Mcl-1, in human cells. By biology-guided fractionation we isolated the flavonoid, luteolin, which downregulates Mcl-1 by inhibition of Cdk9 in vitro and subsequent inhibition of RNA polymerase II phosphorylation.

\section{Methods}

\section{Plant Collection and Extract Preparation}

Thermopsis rhombifolia aerial parts were collected at undisturbed sites near Lethbridge, AB, Canada. The taxonomical classification was confirmed by the University of Lethbridge Herbarium and using botanical criteria [6], and voucher specimens (\#672), \#Golsteyn020 and \#Golsteyn120 have been deposited in the University of Lethbridge Herbarium. Aerial parts were cleaned, dried at $40^{\circ} \mathrm{C}$ and stored in dark paper bags at room temperature until used. Extractions were prepared by grinding dried material to a fine powder and suspending it in $75 \%$ ethanol $(10 \mathrm{x} \mathrm{w} / \mathrm{v})$ with stirring overnight. The solute fraction was collected by vacuum filtration and dried under reduced pressure. The dried extracted material was weighed, named PP-020 and stored in darkness at room temperature. For testing in biological assays, samples of dried extracts were dissolved in DMSO to $50 \mathrm{mg} / \mathrm{mL}$ or $100 \mathrm{mg} / \mathrm{mL}$. Extracts in DMSO were stored at $-20^{\circ} \mathrm{C}$.

\section{Extraction and Subfractionation of Thermopsis Rhombifolia}

Dried aerial parts of T. rhombifolia (100 g) were finely powdered and macerated overnight with a solution of ethanol/ $\mathrm{H}_{2} \mathrm{O}(75: 25)$ at room temperature. After vacuum filtration on paper filter, the solute was concentrated under reduced pressure. The crude extract (28.6 g) was further subjected to silica column chromatography on prepacked cartridge Kieselgel $(40 \mathrm{~g}, 40 \times 100 \mathrm{~mm}$, 40-60 $\mu \mathrm{m}$ ) using a $\mathrm{CH}_{2} \mathrm{Cl}_{2}-\mathrm{MeOH}$ gradient [1:0 to 0:1], to give 10 fractions ( $20 \mathrm{~mL}$ each). All fractions were analyzed by TLC on silica gel $60 \mathrm{~F}_{254}$ (Merck) using the solvent mixture $\mathrm{CH}_{2} \mathrm{Cl}_{2}-\mathrm{MeOH}(90: 10)$ and submitted in parallel to a bio guided selection. Spots were visualized by heating after spraying with $3 \% \mathrm{H}_{2} \mathrm{SO}_{4}+1 \%$ vanillin.

Fraction TR/05-01 showing anti Mcl-1 activity was submitted to subfractionation. TR/05-01 (49 mg) was prepared by repeated semipreparative Waters HPLC RP-18 chromatography equipped with a 600 pump, a 486 Tunable absorbance detector and EZChrom software. Subfractions were collected from a prepacked $\mathrm{C}_{18}$ reversed-phase column (Xbridge RP-18, 19×250 mm, $10 \mu \mathrm{m}$ ) with a binary gradient elution (solvent $\mathrm{A}: \mathrm{H}_{2} \mathrm{O}$ and solvent $\mathrm{B}: \mathrm{MeCN}$ ), a flow rate of $20 \mathrm{~mL} / \mathrm{min}$ and the chromatogram was monitored between 210 and $380 \mathrm{~nm}$.

\section{Cell Culture}

The human cell lines HT-29 (colorectal carcinoma; ATCC HTB-38), M059K (glioblastoma; ATCC CRL2365) and WI-38 (normal diploid human lung fibroblasts; ATCC CCL-75) were obtained from the American Type Culture Collection (ATCC). HT-29 cells were maintained in RPMI 1640 medium (Gibco; 21870-092) supplemented with $10 \%(\mathrm{v} / \mathrm{v})$ heat inactivated fetal bovine serum (FBS) (Gibco; 12484028) and 1.6 mM GlutaMAX (Gibco; 35050-061). M059K cells were maintained in Dulbecco's Modified Eagle Medium (DMEM)/F-12 (Gibco; 11320-082) supplemented with $10 \%(\mathrm{v} / \mathrm{v})$ heat inactivated FBS (Gibco; 12484028), 2 mM Modified Eagle Medium non-essential amino acids (Gibco; 11140050) and $15 \mathrm{mM}$ HEPES (4-(2-hydroxyethyl)-1-piperazineethanesulfonic acid), $\mathrm{pH}$ 7.4. WI-38 cells were maintained in DMEM/High glucose (Sigma; D6546) supplemented with 10\% heat inactivated FBS (Gibco; 12484028), 2 mM Modified Eagle Medium non-essential amino acids (Gibco; 11140050), and $1.6 \mathrm{mM}$ GlutaMAX (Gibco; 35050061). Cells were grown at $37^{\circ} \mathrm{C}$ in $5 \% \mathrm{CO}_{2}$ and $90 \%$ humidity atmosphere and the media were replaced every two-three days. HT-29 cells were plated at a density of $1.0 \times 10^{6}$ cells $/ 75 \mathrm{~cm}^{2}$ flask and cultured for $48 \mathrm{~h}$ prior to treatment. M059K and WI-38 cells were plated 
at $5.0 \times 10^{5}$ cells $/ 75 \mathrm{~cm}^{2}$ flask and cultured for $48 \mathrm{~h}$ prior to treatment. All compounds, plant extract fractions, and subfractions were dissolved in DMSO for treatment. Luteolin (Cayman Chemical Co.; 10004161), daidzein (Cayman Chemical Co.; 10005166), genistein (Cayman Chemical Co.; 10005167) and quercetin (Sigma; Q4951) were dissolved in DMSO (SigmaAldrich; D2438) to $5 \mathrm{mg} / \mathrm{mL}$. CR8 (Tocris Biosciences; 3605) and camptothecin (CPT; Sigma; 7689-03-4) were dissolved to $10 \mathrm{mM}$; palbociclib (LC Laboratories; P-7788) and staurosporine (STS; Cayman Chemical Co.; 81590) were dissolved to $1 \mathrm{mM}$, and nocodazole (Sigma; M1404) was dissolved to $200 \mathrm{mg} / \mathrm{mL}$. Not treated (NT) refers to vehicle controls in which cells were treated with DMSO only.

\section{Cytotoxicity Assays}

The cytotoxicity of T. rhombifolia extracts $(100 \mathrm{mg} / \mathrm{mL})$ or subfractions was measured by (3-(4,5-dimethylthiazol-2-yl)-2,5-diphenyltetrazolium bromide) tetrazolium (MTT) reduction assay (Sigma; M2128-1G). HT-29, M059K and WI-38 cells were plated at 10,000, 4000 and 4000 cells per well with 200 uL medium per well in 96 well culture plates, respectively, and cultured for $72 \mathrm{~h}$ prior to treatment. At $96 \mathrm{~h}$ after treatment, $20 \mu \mathrm{L}$ MTT solution $(5 \mathrm{mg} / \mathrm{mL}$ MTT in PBS $(137 \mathrm{mM}$ $\left.\mathrm{NaCl}, 3 \mathrm{mM} \mathrm{KCl}, 100 \mathrm{mM} \mathrm{Na}_{2} \mathrm{HPO}_{4}, 18 \mathrm{mM} \mathrm{KH}_{2} \mathrm{PO}_{4}\right)$ ) was added to the media in each well and the plates were incubated at $37^{\circ} \mathrm{C}$ for $3.5 \mathrm{~h}$. The media was then aspirated and $100 \mu \mathrm{l}$ MTT solvent $(4 \mathrm{mM} \mathrm{HCl}, 0.1 \%$ (v/v) octylphenoxypolyethoxyethanol, in isopropanol) was added to each well. Plates were shaken for $30 \mathrm{~min}$ in the dark, and absorbance was measured at $590 \mathrm{~nm}$ using a BioTek Epoch microplate spectrophotometer operated by Gen 5.0 software. Results were expressed as IC50 concentrations; the concentration of the compound that reduced the absorbance of MTT by $50 \%$. The percent absorbance was determined by normalization to $0.1 \%(\mathrm{v} / \mathrm{v})$ DMSO-treated cells. The log concentrations of the compound were plotted against the normalised percent absorbance using Microsoft Excel 2016 software. Analysis was performed with GraphPad Prism 5 software, using non-linear regression (log(inhibitor) versus normalised response), to estimate the IC50 concentrations. Standard curves were plotted using the equation: $\mathrm{Y}=$ maximum $+($ maximum - minimum $) /$ $\left(1+10^{(\mathrm{x}-\log [\mathrm{C50})}\right)$, where maximum is the percentage of viable cells after treatment with $0.1 \%$ DMSO, minimum is the percentage of viable cells after treatment with the highest concentration of the treatment and $\mathrm{x}$ is the log 10 value of the treatment concentration. All measurements were performed in triplicate and experiments were performed three times.

\section{Flow Cytometry}

HT-29 cells were plated at $1 \times 10^{6}$ cells $/ 75 \mathrm{~cm}^{2}$ flask and incubated at $37^{\circ} \mathrm{C}$ for $72 \mathrm{~h}$ prior to treatment. Treated cells were collected by trypsinization, washed with $1 \%$ (w/v) BSA in PBS and fixed in ice-cold 90\% ethanol for at least $24 \mathrm{~h}$. Fixed samples were stored at $-20^{\circ} \mathrm{C}$ until analyzed. For analysis, samples were centrifuged at 750 $\mathrm{g}$ for $5 \mathrm{~min}$ at $4^{\circ} \mathrm{C}$ and washed with ice-cold PBS. Cells were then washed twice with ice-cold wash buffer $(1 \%$ $(\mathrm{w} / \mathrm{v}) \mathrm{BSA}$ in PBS) then incubated with labelling buffer (1\% (w/v) BSA (Fisher; AAJ6465522), $20 \mu \mathrm{g} / \mathrm{mL}$ propidium iodide (PI; Life Technologies; P1304MP) and $200 \mu \mathrm{g} / \mathrm{mL}$ RNAse A (Sigma; R6513-250MG in PBS) for $30 \mathrm{~min}$. Samples were analysed by a FACSAria fusion flow cytometer (BD Biosciences) using BD FACSDiva software (BD Biosciences). Gating was set using cells treated with DMSO or nocodazole. Experiments were performed three times.

\section{Electrophoresis and Western Blotting}

Treated cells were washed with ice-cold PBS and collected directly into 1X SDS sample buffer (1\% SDS, $12.5 \%$ glycerol, $50 \mathrm{mM}$ Tris ( $\mathrm{pH} 6.8$ ), $50 \mathrm{mM}$ DTT, $0.005 \%$ bromophenol blue) with a cell scraper. Cells were heated at $95^{\circ} \mathrm{C}$ for $5 \mathrm{~min}$, vortexed, cooled and centrifuged at $10,000 \mathrm{~g}$ for $10 \mathrm{~min}$ at $4^{\circ} \mathrm{C}$ to collect debris. Cell extracts were separated by $10 \%$ (v/v) SDSPAGE and Precision Plus Dual Colour marker (BioRad; 161-0394) was used to determine molecular weight in kilodaltons $(\mathrm{kDa})$. Proteins were transferred onto nitrocellulose membranes by wet transfer and transfer was confirmed using Ponceau $S$ stain $(0.1 \%(w / v)$ in $5 \%$ acetic acid). Membranes were blocked with either 5\% (w/v) low-fat milk or $2 \%(\mathrm{w} / \mathrm{v})$ BSA in Tris-buffered saline (TBS) with Tween-20 (TBS-T) (50 mM Tris base, 150 $\mathrm{mM} \mathrm{NaCl}$ and $0.1 \%(\mathrm{v} / \mathrm{v})$ Tween-20, $\mathrm{pH}$ 7.6) for $1 \mathrm{~h}$. Membranes were then incubated with one the following primary antibodies at $4^{\circ} \mathrm{C}$ overnight: anti-actin (Santa Cruz Biotechnology; sc-58673; 1:200); anti-cleaved PARP (Asp214) (Cell Signaling Technology; 5625; 1:100), anti-Mcl-1 (Santa Cruz Biotechnology; sc-819; 1:100), anti-histone $\gamma \mathrm{H} 2 \mathrm{AX}$ (Millipore; 05-636; 1:200), anti- Bcl-xL (Cell Signaling Technology; 2764; 1:1000), anti-RNA polymerase II CTD (Cell Signaling Technology; 2629S; 1:1000), anti-phospho-Ser2/5 RNA polymerase II CTD RNA polymerase II CTD (Cell Signaling Technology; 4735S; 1:1000), anti-Cdk4 (Cell Signaling Technology; 12790S; 1:1000) or anti-Cdk9 (Cell Signaling Technology; 2316S; 1:1000). The membranes were then washed with TBS-T and incubated with the following secondary antibodies for $1 \mathrm{~h}$ at room temperature: alkaline phosphatase-coupled anti-mouse IgG (Promega; PRS3721; 1:2500) or alkaline phosphatase 
coupled anti-rabbit IgG (Promega; PRS3731; 1:2500). The membranes were washed with TBS-T and developed using an alkaline phosphatase conjugate substrate kit (BioRad; 172-1063). Development was stopped with Tris-EDTA (diaminoethane tetra-acetic acid) buffer (10 mM Tris base, $1 \mathrm{mM}$ EDTA, pH 8.0). Western blot analyses were performed three times and anti-actin analysis was used to compare sample loading.

\section{Protein Kinase Assays}

Kinase activities were quantified according to the radiometric assay described in [7]. Kinase assays were performed in the presence of $15 \mu \mathrm{M}\left[\gamma^{-}{ }^{33} \mathrm{P}\right]$ ATP $(3000 \mathrm{Ci} /$ $\mathrm{mmol} ; 10 \mathrm{mCi} / \mathrm{mL}$ ) with either protein or peptide as substrate and using the appropriate buffer (described hereafter). Controls were performed with appropriate dilutions of dimethylsulfoxide (DMSO). The peptides were obtained from Proteogenix, Oberhausbergen, France. To perform the experiments described in this article, we used the product provided by GE Healthcare (ref\# 3698-915, Grade P81 Ion Exchange Paper) or Millipore Sigma ${ }^{\text {tw }}$ MultiScreen ${ }^{\text {tm }}$ HTS 96-Well Filter Plates (provided by Fisher Scientific, product \#MSPHN6B10) with negatively charged membrane. The buffers used in this study are: (Buffers A) $10 \mathrm{mM}$ $\mathrm{MgCl}_{2}, 1 \mathrm{mM}$ EGTA, $1 \mathrm{mM}$ DTT, $25 \mathrm{mM}$ Tris-HCl pH 7.5, $50 \mu \mathrm{g} / \mathrm{mL}$ heparin; (Buffer B) $60 \mathrm{mM}$ b-glycerophosphate, $30 \mathrm{mM}$ p-nitrophenyl-phosphate, $25 \mathrm{mM}$ MOPS (pH 7), $5 \mathrm{mM}$ EGTA, $15 \mathrm{mM} \mathrm{MgCl}, 1 \mathrm{mM}$ DTT, $0.1 \mathrm{mM}$ sodium orthovanadate; (Buffer C) $60 \mathrm{mM}$ ß-glycerophosphate, $15 \mathrm{mM}$ p-nitrophenyl-phosphate, $25 \mathrm{mM}$ MOPS (pH 7.2), 5 mM EGTA, $15 \mathrm{mM} \mathrm{MgCl}_{2}$, $1 \mathrm{mM}$ DTT. The following kinases were analysed is this

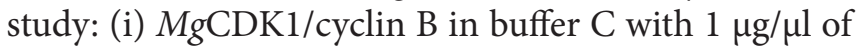
histone $\mathrm{H} 1$ as substrate; (ii) $\mathrm{HsCDK} 2 / \mathrm{CyclinA}$ (cyclindependent kinase-2, human in buffer A (with 0.15 $\mathrm{mg} / \mathrm{mL}$ of BSA and $0.23 \mathrm{mg} / \mathrm{mL}$ of DTT) and with 0.8 $\mu \mathrm{g} / \mu \mathrm{L}$ of histone $\mathrm{H} 1$ as substrate; (iii) $\mathrm{HsCDK} 5 / \mathrm{p} 25$ (human, recombinant) was assayed in buffer B, with 0.8 $\mu \mathrm{g} / \mu \mathrm{L}$ of histone $\mathrm{H} 1$ as substrate; (iv) $\mathrm{HsCDK} 9 / \mathrm{CyclinT}$ (human, recombinant) was assayed in buffer A (with 0.15 $\mathrm{mg} / \mathrm{mL}$ of BSA and $0.23 \mathrm{mg} / \mathrm{mL}$ of DTT) and with 0.27 $\mu \mathrm{g} / \mu \mathrm{L}$ of the peptide, YSPTSPSYSPTSPSYSPTSPSKKKK, as substrate; (v) SscGSK-3a/ $\beta$ (glycogen synthase kinase-3, porcine in buffer A (with $0.15 \mathrm{mg} / \mathrm{mL}$ of BSA and $0.23 \mathrm{mg} / \mathrm{mL}$ of DTT) and with 0.010 $\mu \mathrm{g} / \mu \mathrm{L}$ of GS-1 peptide, a GSK-3-selective substrate (YRRAAVPPSPSLSRHSSPHQSpEDEE, where "Sp" stands for phosphorylated serine).

\section{Cellular Thermal Shift Assay}

Cellular thermal shift assays were performed on HT-29 cells using the method described previously $[8,9]$. Briefly,
HT-29 cells were plated at $5 \times 10^{6}$ cells $/ 175 \mathrm{~cm}^{2}$ flask and incubated at $37^{\circ} \mathrm{C}$ for $72 \mathrm{~h}$ prior to treatment. Cells were then treated for $1 \mathrm{~h}$, collected by trypsinization, counted and resuspended at $30 \times 10^{6}$ cells $/ \mathrm{mL}$ into PBS supplemented with protease inhibitors (Sigma; 11836170001). The cell suspension was distributed equally into PCR tubes at $3 \times 10^{6}$ cells/tube. Tubes were heated to different temperatures for $3 \mathrm{~min}$ using a pre-heated thermal cycler (Eppendorf Mastercycler Pro), followed by incubation at room temperature for $3 \mathrm{~min}$ and snap-freezing in liquid nitrogen. Cells were then lysed by two rounds of freezethaw using liquid nitrogen and a heating block set at $25^{\circ} \mathrm{C}$, with vortexing between steps. The lysates were centrifuged at $20,000 \mathrm{~g}$ for $20 \mathrm{~min}$ at $4^{\circ} \mathrm{C}$ and the supernatant removed for analysis. Soluble protein was detected by western blot analysis as described above using antiCdk 4 or anti-Cdk 9 antibodies and signals were quantified using Image J software (1.50f). The signals from each temperature were then normalized by setting the highest and lowest value in each set to 100 and $0 \%$.

\section{Identification of Luteolin from Thermopsis Rhombifolia}

Analytical HPLC was performed on a Merck-Hitachi apparatus equipped with an L-7200 automated sample injector, a L-7100 pump, a L-7450 diode array detector, a D-7000 interface and EZChrom software. Luteolin isolated as solid $(9.7 \mathrm{mg})$. Its elemental formula was established by high resolution mass spectrometry as $\mathrm{C}_{15} \mathrm{H}_{2} \mathrm{ON}_{2} \mathrm{O}$. HRESIMS m/z 245.1650 (calculated for $\mathrm{C}_{15} \mathrm{H}_{2} \mathrm{ON}_{2} \mathrm{O}: 245.1648$ ) and structure confirmed by $2 \mathrm{D}$ NMR on a Bruker Avance II spectrometer equipped with a $13 \mathrm{C}$ cryoprobe at $500 \mathrm{MHz}$ for $1 \mathrm{H}$ and $125 \mathrm{MHz}$ for $13 \mathrm{C}$ using standard Bruker software.

Analysis of luteolin isolated from T. rhombifolia and commercially purchased luteolin was performed using a Symmetry C18 (Waters) column (100A, $3.5 \mu \mathrm{m}$, $4.6 \mathrm{~mm} \times 75 \mathrm{~mm}$ ) at room temperature on a Waters 1525 Binary HPLC System coupled to a UV/Visible detector operated by Breeze 2 software. Samples were dissolved to $100 \mathrm{mg} / \mathrm{mL}$ and $5 \mu \mathrm{L}$ was loaded with a loop injector. The samples were eluted using formic acid $(0.1 \%)$ as solvent $\mathrm{A}$ and acetonitrile as solvent $\mathrm{B}, 0-15 \mathrm{~min}$ from $15 \% \mathrm{~B}$ to $60 \% \mathrm{~B}$ and a flow rate of $1.0 \mathrm{~mL} / \mathrm{min}$. A $10 \mathrm{~min}$ re-equilibration was used between runs. UV-Vis spectra were recorded at a detection wavelength of $360 \mathrm{~nm}$ and retention time was determined by Breeze 2 software.

\section{Statistical Analysis}

Data were analyzed using Microsoft Excel 2016 and GraphPad Prism 5 software. Data were plotted as means \pm standard error of the means. Statistical significance was calculated by one-way ANOVA with Tukey HSD 
(honest significant difference) post-hoc analysis. Values were considered significantly different when $p<0.05$.

\section{Results}

\section{Extracts Prepared from Thermopsis Rhombifolia are Cytotoxic to Human Cells}

We previously identified an extract (PP-003) from the prairie plant species, Thermopsis rhombifolia (Fabaceae) as a source of natural products that arrest cells in the cell cycle [10]. We proceeded to investigate the chemicals responsible this effect by preparing T. rhombifolia $75 \%$ ethanol extractions named PP-020 and confirming its toxicity against human cell lines. Colorectal adenocarcinoma (HT-29), malignant glioblastoma (M059K) and normal lung fibroblast cell lines (WI-38) were treated with either DMSO or with different concentrations of PP-020 for $96 \mathrm{~h}$ and viability was measured as $\mathrm{IC}_{50}$ values using the MTT assay (Figure 1). The M059K cells were the most sensitive, with an $\mathrm{IC}_{50}$ of $90 \pm 14 \mu \mathrm{g} / \mathrm{mL}$.
The least sensitive cells were the normal diploid fibroblasts, WI-38 with an $\mathrm{IC}_{50}$ of $240 \pm 34 \mu \mathrm{g} / \mathrm{mL}$, whereas HT-29 cells displayed a value of $130 \pm 8 \mu \mathrm{g} / \mathrm{mL}$. These data indicated that extract PP-020 was toxic to human cultured cells and there was a period of 96 hours in which pathways might be inhibited by PP-020 to cause cell death.

\section{T. Rhombifolia Extract PP-020 Inhibits Cdk9 and Reduces Mcl-1 Protein Levels}

We had previously demonstrated that $T$. rhombifolia extracts arrest cells in the G1 phase of cell cycle without engaging a DNA damage response [10]. This type of cell cycle arrest is a characteristic of cyclin dependent kinase (Cdk) inhibitors, therefore, we sought to investigate whether extract PP-020 could inhibit a panel of protein kinases that included several members of the CMGC group (Cdks, mitogen-activated protein kinases, glycogen synthase kinases and CDK-like kinases) (Figure 2A). PP-020 inhibited Cdk9/cyclin T

B

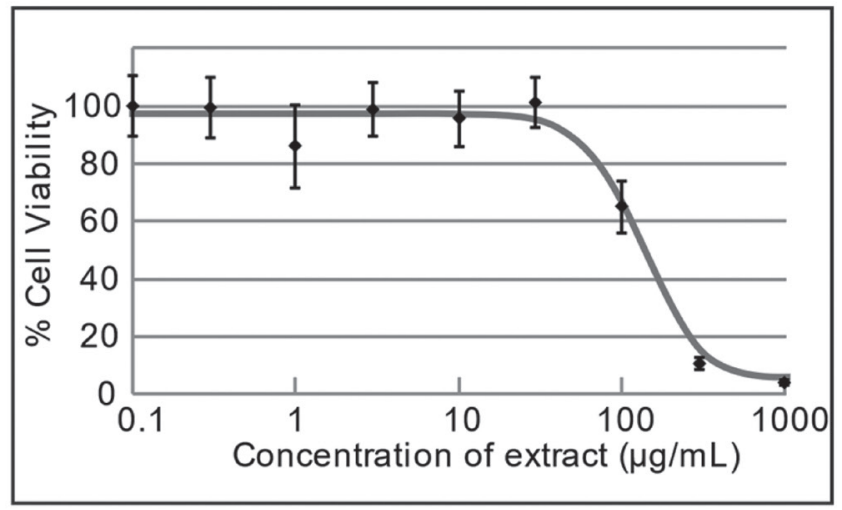

C

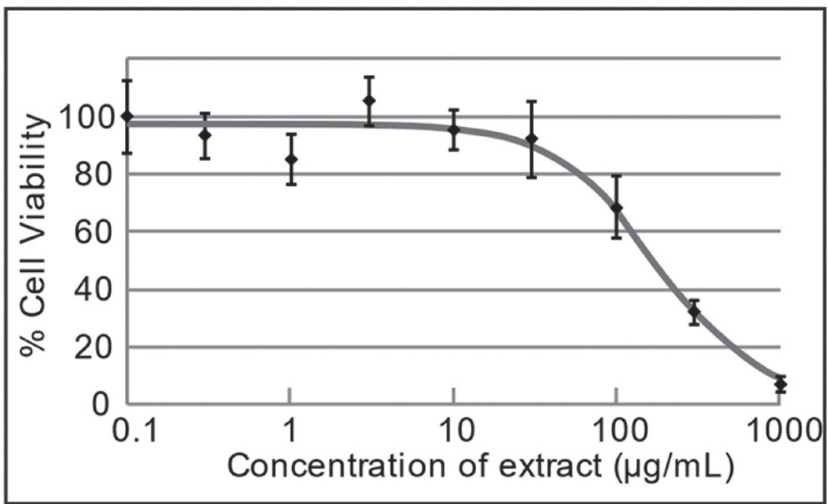

Figure 1. Extracts from Thermopsis rhombifolia are toxic to cultured human cells Varying concentrations of extract PP-020 from T. rhombifolia were used to treat either M059K (A); HT-29 (B); or WI-38 (C) cells and viability at $96 \mathrm{~h}$ was measured by the MTT assay. Mean percentages of viability were calculated and standard errors of the means are shown. The mean $I_{50}$ concentrations were: (A) $90 \pm 14 \mu \mathrm{g} / \mathrm{mL}$; (B) $130 \pm 9 \mu \mathrm{g} / \mathrm{mL}$; (C) $240 \pm 34 \mu \mathrm{g} / \mathrm{mL}$. 
A

\begin{tabular}{|l|c|}
\hline Enzyme & $\begin{array}{c}P P-020 \\
\mathrm{IC} 50(\mu \mathrm{g} / \mathrm{mL})\end{array}$ \\
\hline CDK1 & $>10$ \\
\hline CDK2/A & $>10$ \\
\hline CDK5 & $>10$ \\
\hline CDK9/cyclin T & 0.5 \\
\hline GSK3 & $>10$ \\
\hline
\end{tabular}

B

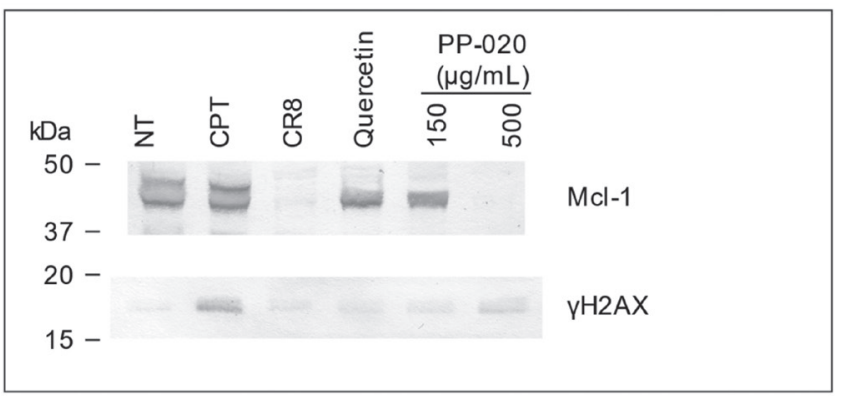

C

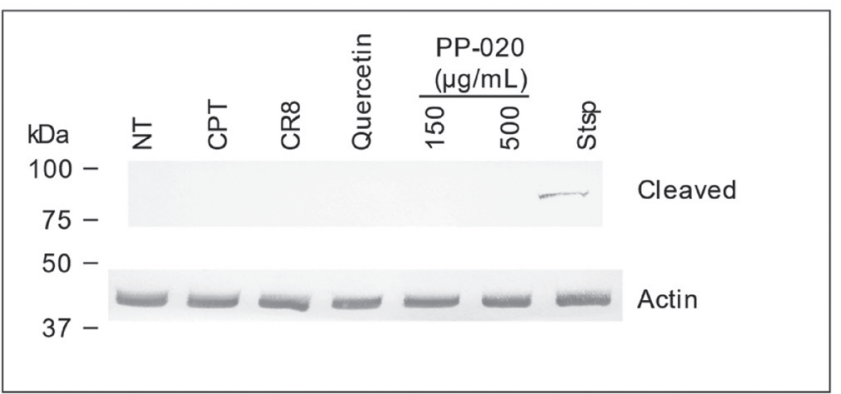

Figure 2. Extract PP-020 from T. rhombifolia inhibits Cdk9 and induces the reduction of $\mathrm{Mcl}-1$ protein levels in cells. (A) PP-020 was tested in biochemical assays for Cdk1, Cdk2/A, Cdk5, Cdk9/cyclin T, or GSK3 and $\mathrm{IC}_{50}$ values or maximum tested concentrations are shown. (B) HT-29 cells were either not treated (NT) or treated with $50 \mathrm{nM}$ CPT, $1 \mu \mathrm{M}$ CR8, $50 \mu \mathrm{M}$ quercetin, either 150 or $500 \mu \mathrm{g} / \mathrm{mL}$ of PP-020 for $24 \mathrm{~h}$ and total cell extracts were prepared. Samples were analysed by western blotting using anti-Mcl-1, anti-yH2AX. Molecular markers in kDa are shown on left. (C) HT-29 cells were either not treated (NT) or treated as described in $\mathrm{B}$, or with $1 \mu \mathrm{M}$ staurosporine (Stsp) for $24 \mathrm{~h}$ and total cell extracts were prepared. Samples were analysed by western blotting using anti-cleaved PARP or anti-actin antibodies. Molecular markers in $\mathrm{kDa}$ are shown on left.

at an $\mathrm{IC}_{50}$ of $0.5 \mu \mathrm{g} / \mathrm{mL}$ whereas Cdk1/cyclin $\mathrm{B}, \mathrm{Cdk} 2 /$ cyclin $\mathrm{A}, \mathrm{Cdk} 5 / \mathrm{p} 25$, or the glycogen synthase kinase 3 $\mathrm{a} / \mathrm{b}(\mathrm{GSK}-3 \alpha / \beta)$, were not inhibited at concentrations up to $10 \mu \mathrm{g} / \mathrm{mL}$ of PP- 020 .

We reasoned that if extract PP-020 could inhibit the Cdk9/cyclin T complex in cells then the levels of short-lived proteins, such as Mcl-1, would be reduced in treated cells [11]. To test this, HT-29 cells were either not-treated (NT), or treated with different concentrations of PP-020. In addition, we tested HT-29 cells with representative compounds to provide insight into the specificity of cellular responses. These included camptothecin (CPT) to damage DNA [12]; CR8, a pan-Cdk inhibitor that induces cell cycle arrest and reduces Mcl-1 levels [11]; quercetin a flavonoid common to Fabaceae [13]. Cells were collected and examined by Western blotting (Figure 2B). We observed that NT cells contained Mcl-1 and CR8-treated cells had low levels of Mcl-1, as expected. Strikingly, cells treated with $500 \mu \mathrm{g} / \mathrm{mL}$ PP-020 also had low levels of Mcl-1, whereas CPT, quercetin or a $150 \mu \mathrm{g} / \mathrm{mL}$ concentration of PP-020 had little effect. CPT treated cells, however, revealed a histone gamma H2AX signal characteristic of damaged DNA, whereas only a weak signal was detected in $500 \mu \mathrm{g} / \mathrm{mL}$ PP-020 treated cells.

We next compared PP-020 treated cells to cells engaged in apoptosis by staurosporine (STS) treatment (Figure 2C). We monitored cells by western blot analysis for the Poly (ADP-ribose) polymerase (PARP) cleavage product, which is present in apoptotic cells [14]. STS treated cells revealed a PARP cleavage product whereas no signals were observed for PP-020 treated cells or other treatments. Equal amounts of cell proteins were loaded for each treatment as confirmed by anti-actin antibodies. These data indicated that PP-020 causes a reduction in Mcl-1 levels in cells that was consistent with an inhibition of $\mathrm{Cdk} 9 /$ cyclin $\mathrm{T}$ in biochemical assays. In addition, apoptotic and DNA damage pathways were not activated after treatment with PP-020 for $24 \mathrm{~h}$.

\section{Luteolin Isolation from PP-020 Extracts by Biology-Guided Fractionation Using Mcl-1 Activity}

The capacity of PP-020 to reduce Mcl-1 levels in treated cells provided us with an assay to identify the active chemical. We first determined which aerial plant part contained the anti-Mcl-1 activity (Figure 3A). T. rhombifolia plants were separated into leaves (L.E.), flowers (F.E.) or woody stem parts (S.E.) and equal amounts of each were extracted under similar conditions. In addition, leaves from T. rhombifolia collected at a different year from that of PP-020, named PP-029 were also extracted and tested. Cells were either not-treated (NT), treated with CR8, or with extracts prepared from different T. rhombifolia parts and plants. Mcl-1 was present in NT cells and in reduced amounts in CR8 treated cells, as expected. L.E., S.E. and PP-029 extracts reduced Mcl-1 levels in treated cells, whereas F.E. treated cells contained Mcl-1. By actin western blotting, we confirmed that similar amounts of total cellular proteins were tested under each treatment. 
A

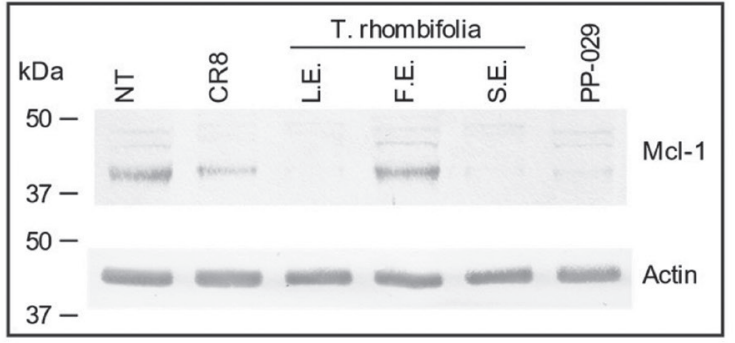

B

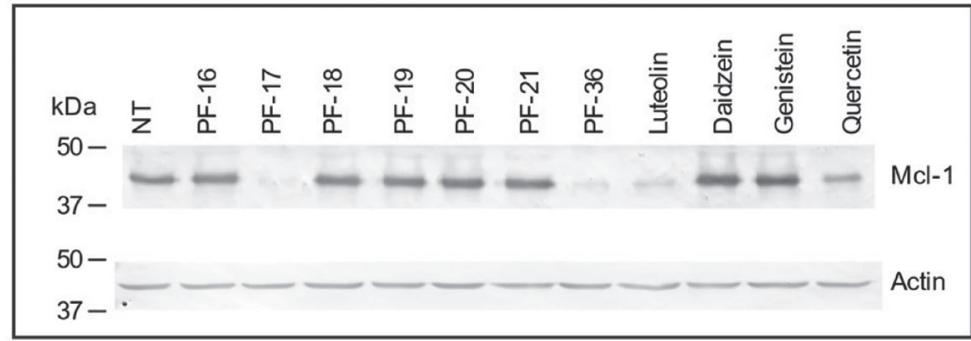

C

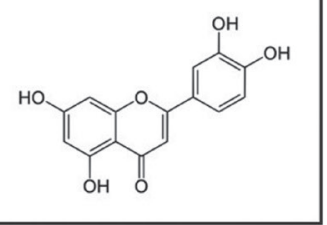

D

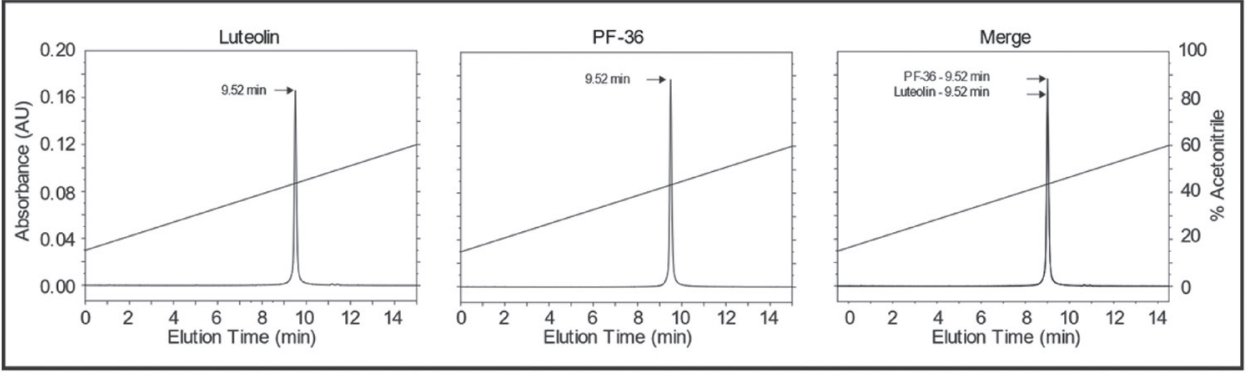

Figure 3. Luteolin, isolated from T. rhombifolia, induces a reduction in Mcl-1 levels in cells. (A) HT-29 cells were either not treated (NT) or treated with $1 \mu \mathrm{M}$ CR8, or $500 \mu \mathrm{g} / \mathrm{mL}$ of either T. rhombifolia leaf extract (L.E.), flower extract (F.E) or stem extract (S.E.), or $500 \mu \mathrm{g} / \mathrm{mL}$ of T. rhombifolia L.E. from an independent collection (PP-029) for $24 \mathrm{~h}$ and HT-29 samples were analysed by western blotting using anti-Mcl-1 or anti-actin antibodies. Molecular markers in kDa are shown on left. (B) HT-29 cells were either not treated (NT) or treated with $50 \mu \mathrm{g} / \mathrm{mL}$ of either PP-020 partially subfractions (PF16-21), purified PF-36 or various flavonoid compounds for $24 \mathrm{~h}$ and total cell extracts were prepared and analysed by western blotting using Mcl-1 or actin antibodies. Molecular markers in kDa are shown on left. (C) The chemical structure of luteolin is shown. (D) HPLC chromatograms of $0.5 \mu g$ each of luteolin or PF-36 were analyzed by reverse-phase C18 column and gradient elution. Arrows indicate retention times for PF-36 (9.52 min) and luteolin (9.52 min). The chromatograms are merged for comparison in the right panel.

We undertook several rounds of biology-guided purification in which HT-29 cells were treated with various subfractions of increasing purity of chemicals to determine their capacity to reduce Mcl-1 levels. In a representative experiment, we observed that cells treated by fraction PF-17 had reduced Mcl-1 levels (Figure 3B). A pure chemical was isolated (PF-36) and identified as the flavone, luteolin (Figure 3C). We tested other flavonoid chemicals, including commercially available luteolin, the isoflavones daidzein, genistein, and the flavonol quercetin, at similar concentrations and showed that luteolin was the most effective of these (Figure 3B). To confirm further that luteolin isolated from T. rhombifolia was the source of anti-Mcl-1 activity, we compared its elution profile by HPLC to a commercially available luteolin and found that the two profiles were identical (Figure 3D).

\section{Luteolin is Cytotoxic, Reduces RNA Polymerase II Phosphorylation, and Arrests Cells in the G1 Phase of the Cell Cycle}

Mcl-1 downregulation can sensitize cells to cell death and luteolin was previously reported to be toxic to human cells [15]. Therefore, we confirmed that luteolin reduced cell viability in HT-29 cells. We treated HT-29 cells with $0.01-100 \mu \mathrm{g} / \mathrm{mL}$ of luteolin for $96 \mathrm{~h}$ and measured cell viability by the MTT assay (Figure $4 \mathrm{~A}$ ). We found that luteolin was toxic to HT 29 cells with an $\mathrm{IC}_{50}$ of $7.0 \pm 0.7$ $\mu \mathrm{g} / \mathrm{mL}$ at $96 \mathrm{~h}$. We then tested if another anti-apoptotic protein, Bcl-xL might also be downregulated (Figure 4B). 
A

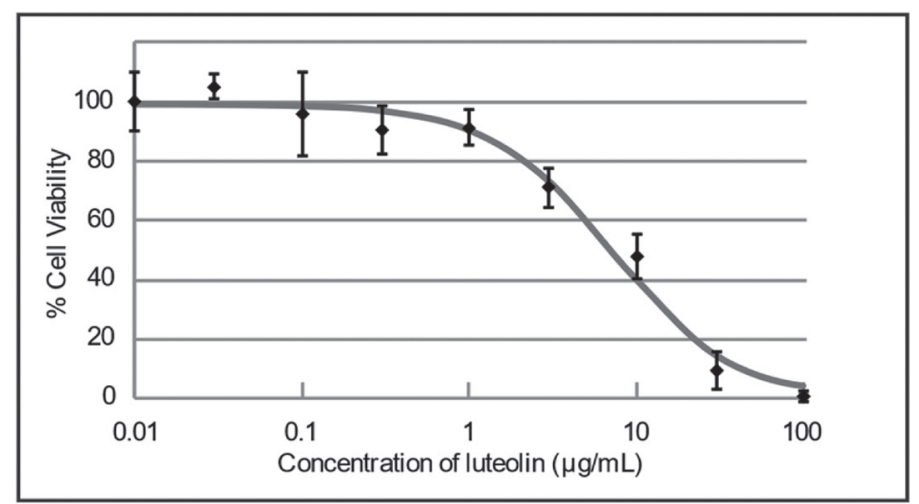

B

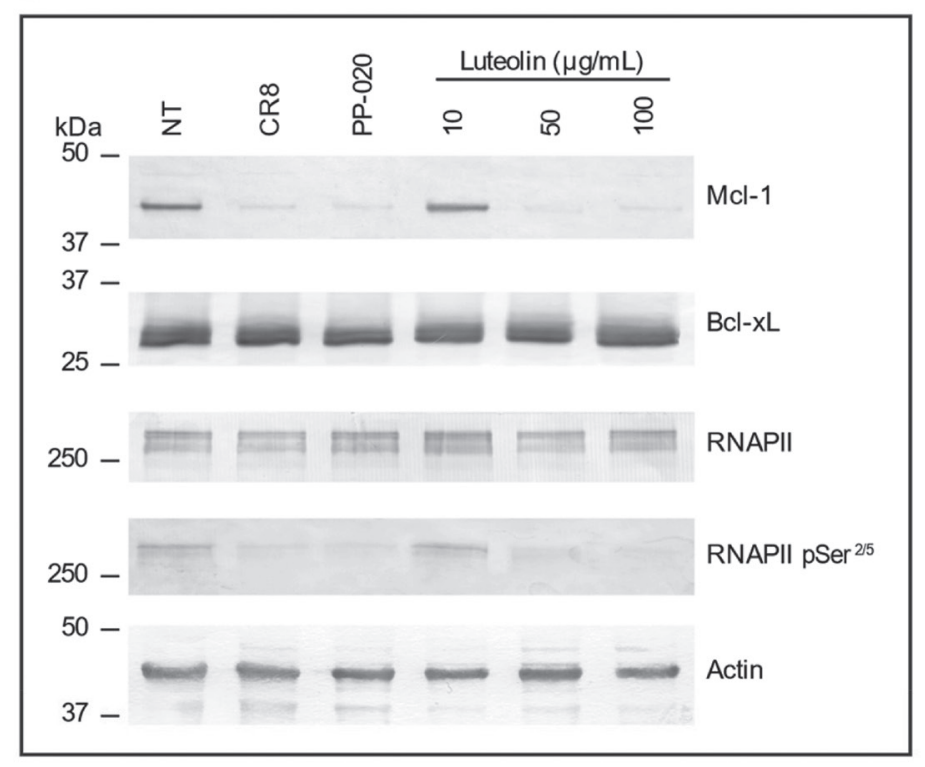

C
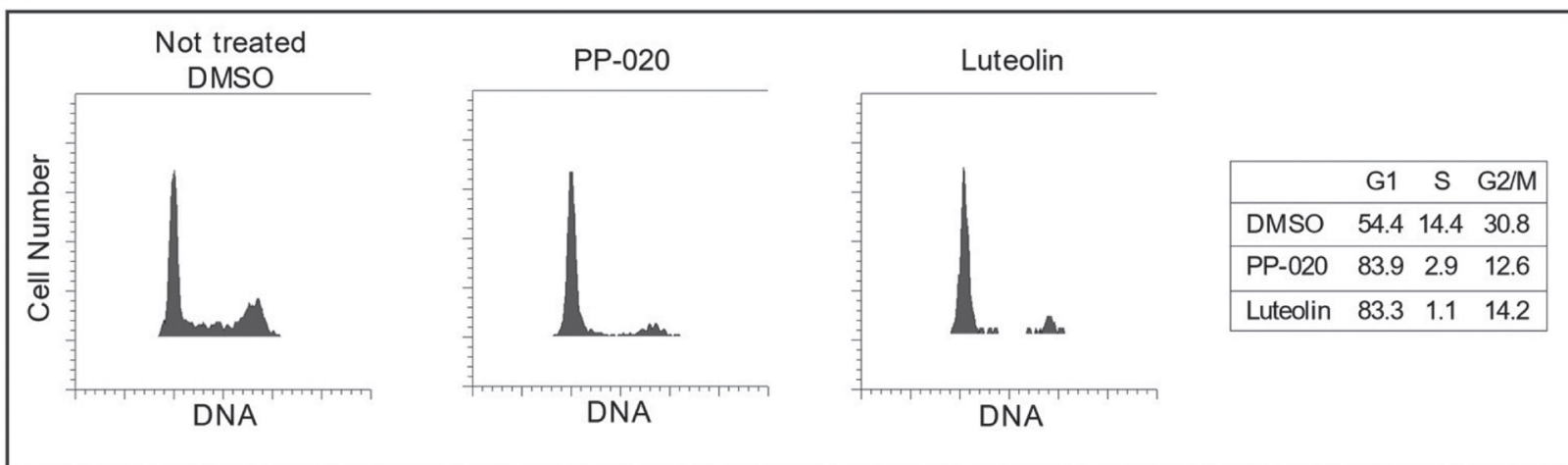

Figure 4. Luteolin, isolated from T. rhombifolia, is cytotoxic, induces a reduction in RNAPIl phosphorylation and arrests cell in the cell cycle. (A) Cells were treated with different concentrations of luteolin and cell viability was determined by the MTT assay as described in Figure 1. The mean IC50 concentration was $7.0 \pm 0.7 \mu \mathrm{g} / \mathrm{mL}$. (B) Cells were either not treated (NT) or treated with $1 \mu \mathrm{M}$ CR8, $500 \mu \mathrm{g} / \mathrm{mL}$ of PP-020, or either 10, 50 or $100 \mu \mathrm{g} / \mathrm{mL}$ of luteolin for $24 \mathrm{~h}$ and total cell extracts were prepared and analysed by western blotting using antibodies anti-RNA polymerase II subunit B1 (RNAPII), anti-phospho-RNAPII (Ser2/5), anti-BCl-XL, anti-Mcl-1 or anti-actin antibodies. Molecular markers in kDa are shown on left. (C) HT-29 cells treated with either DMSO, 500 mg/mL PP-020 or $50 \mu \mathrm{g} / \mathrm{mL}$ luteolin for $24 \mathrm{~h}$. DNA content was analysed by propidium iodide staining. The average percentage of cells in G1, S or G2/M phases of the cell cycle for each condition are given. The experiment was repeated twice. 
We treated cells with 10,50 , or $100 \mu \mathrm{g} / \mathrm{mL}$ of luteolin and compared Mcl-1 and Bcl-xL levels to cells either not treated (NT), treated with CR8 or with PP-020. Nottreated cells maintained a readily detected amount of Mcl-1, and CR8 or PP-020 treated cells had relatively low levels of Mcl-1. We observed a striking reduction in Mcl-1 levels with 50 and $100 \mu \mathrm{g} / \mathrm{mL}$ of luteolin, and a minor reduction with $10 \mu \mathrm{g} / \mathrm{mL}$ at $24 \mathrm{~h}$ treatment. By contrast, the levels of the related $\mathrm{Bcl}-2$ protein, $\mathrm{Bcl}-\mathrm{xL}$, did not change. We reasoned that if T. rhombifolia extract or luteolin treated cells inhibited Cdk9 and reduced Mcl-1 protein levels, then treated cells might have reduced levels of RNA polymerase II (RNAPII) phosphorylation, a known substrate of Cdk9. HT-29 cells treated with CR8 or PP-020 had little RNAPII phosphorylation when compared to NT cells (Figure 4B). Furthermore, cells treated with 50 or $100 \mu \mathrm{g} / \mathrm{mL}$ of luteolin showed little RNAPII phosphorylation, whereas $10 \mu \mathrm{g} / \mathrm{mL}$ luteolin had RNAPII phosphorylation levels comparable to NT. Total RNAPII levels were similar in either NT cells or all treatments.

We have previously reported that cells treated with PP-020 arrest in the G1 phase of the cell cycle. We therefore tested whether cells treated with luteolin arrested in the G1 phase. HT-29 cells either not-treated (NT) or treated for 24 hours with PP-020 or luteolin and analyzed for DNA content by flow cytometry (Figure 4C). NT cells had $54 \%$ of cells in the G1 phase, $14 \%$ in S phase and 30\% in G2/M-phase. By contrast, PP-020 and luteolin treated cells showed a similar cell cycle distribution with $83 \%$ of cells in the G1 phase, less than 3\% of the population in S phase and less than $15 \%$ in the G2/M-phase. These data indicated that luteolin treated cells arrest in the G1 phase of the cell cycle.

\section{Luteolin Protects Cdk9 from Thermodenaturation as Shown by the Cellular Thermal Shift Assay (CETSA)}

Knowing that PP-020 inhibited Cdk9 in biochemical assays and that PP-020 or luteolin could reduce RNAPII phosphorylation levels and Mcl-1 protein levels in cells, we tested if one could detect Cdk9 inhibition by the cellular thermal shift assay (CETSA) [8]. We first confirmed that Cdk4, a member of the Cdk family could be stabilized by the Cdk4 inhibitor PD-0332991 using this method (Figure 5A). Using temperatures between 39 and $65^{\circ} \mathrm{C}$, we were able to detect greater amounts of Cdk4 in solution in the presence of the Cdk4 inhibitor. By contrast, the quantity of Cdk4 in solution did not change in the presence of luteolin when compared to non-treated cells (Figure 5B). We next tested Cdk9 and luteolin, and were able to detect greater amounts of Cdk9 in solution in the presence of luteolin compared to non-treated cells across a temperature range of $44-50^{\circ} \mathrm{C}$ (Figure 5C). These data strongly supported our observations that luteolin inhibits Cdk9 dependent events in treated human cells.

\section{Discussion}

We are investigating Canadian prairie plants for natural products that inhibit vital cellular pathways. This ecological zone harbours a number of plant species that have limited global distribution and have not been explored extensively for natural products. In this study, we expanded on our previous work that showed that extracts prepared from Thermopsis rhombifolia were toxic to human cultured cells and induced a G1 phase arrest [10]. Here we show extracts from this plant inhibit Cdk9 and downregulate the anti-apoptotic protein Mcl-1. By bioassay-guided fractionation, we then purified the natural product flavone, luteolin, and show that it is cytotoxic to cultured cells. Furthermore, we provide evidence that luteolin inhibits Cdk9 in cells, as it reduces phosphorylation of the RNA polymerase II C-terminal domain and induces a G1 phase arrest.

Thermopsis rhombifolia is known by the common names as the buffalo bean or golden bean [16]. It is a prominent plant in Canadian prairies that blooms in May with bright yellow flowers and produces beanlike fruits by mid-summer. If consumed, the plant has been reported to be a source of poisoning in children or livestock [17-19]. The precise toxic ingredients have not yet been identified; however, the abundance of flavones, such as luteolin may contribute to toxicity as we detect here. A number of alkaloids have been previously reported to contribute to toxicity in domestic animals [20]. Extracts prepared from related Thermopsis species present in Turkey have been shown to have potential genotoxic activity or antimicrobial activity [21,22].

The cytotoxicity and cell cycle phase arrest induced by $T$. rhombifolia extracts led to further investigations into the biological pathways inhibited in treated cells. We found that extracts targeted Cdk9, the catalytic subunit of the positive-transcription elongation factor $\mathrm{b}(\mathrm{P}-\mathrm{TEFb})[23,24]$. Cdk9 phosphorylates the carboxy-terminal domain (CTD) of RNA polymerase II (RNAPII) at Ser5 and Ser2. Previous studies have shown that either inhibition of Cdk9 by small molecules, such as flavopiridol, or knockdown of Cdk9 by shRNA, inhibits CTD phosphorylation, which is required for transcription initiation and elongation $[25,26]$. Hence, Cdk9 inhibition reduces transcription, therefore proteins with high turn-over rates, such as Mcl-1, are depleted under these conditions. Mcl-1 is an anti-apoptotic protein with $\mathrm{N}$-terminal motifs that signal proteasomal degradation, 

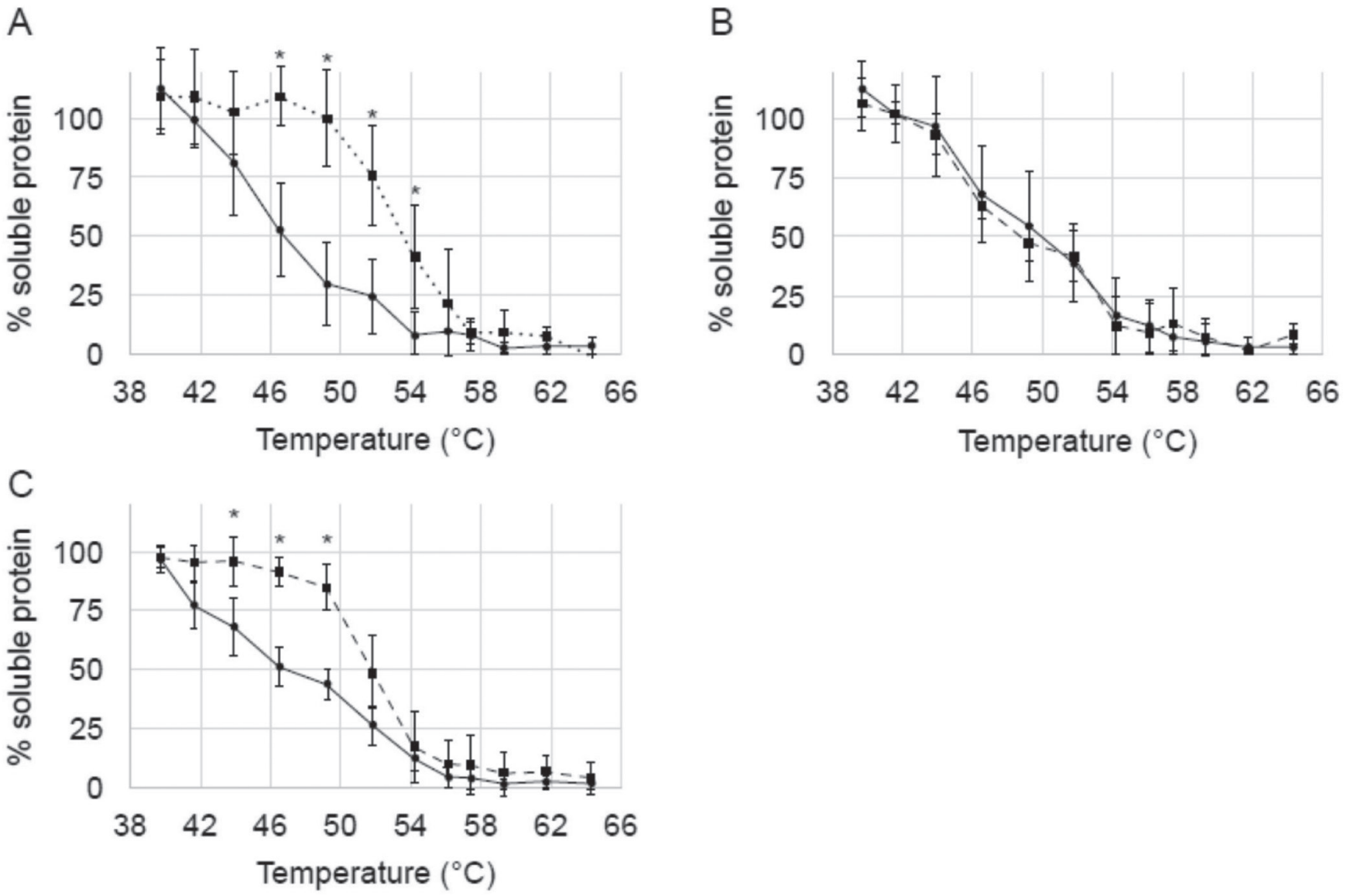

Figure 5. Luteolin protects C k k9 from thermodenaturation but not Cdk4 as shown by CETSA. HT-29 cells were

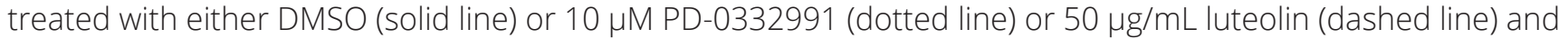
incubated at indicated temperatures for $3 \mathrm{~min}$, followed by western blotting using antibodies against (A) Cdk4 (DMSO, PD-0332991); (B) Cdk4 (DMSO, Luteolin); (C) Cdk9 (DMSO, Luteolin). Data are presented as means \pm SEM for three independent experiments. Significant differences $(p<0.05)$ in soluble protein levels at a temperature are indicated with asterisks $\left(^{*}\right)$.

unlike other Bcl-2 family proteins such as Bcl-xL $[27,28]$. Accordingly, we found that treating cells with T. rhombifolia extracts led to reduced Mcl-1 levels but not reduced Bcl-xL levels.

We used Mcl-1 reduction in a biology-guided fractionation of the leaves of T. rhombifolia to identify the chemical responsible for loss of Mcl-1 protein. We discovered the flavone luteolin as the bioactive compound and confirmed the result by comparing the isolated luteolin to that of commercially available luteolin in bioassays and by HPLC. Consistent with the cellular activity of Thermopsis extracts, luteolin reduced CTD phosphorylation of RNAPII and downregulated Mcl-1 but not Bcl-xL protein. We also found that luteolin induced an arrest in the G1 phase of the cell cycle, confirming reports by others [29-31]. We extended the previous observations by investigating luteolin inhibition by CETSA. Since luteolin did not thermostabilize Cdk4 in the CETSA assay, it is unlikely that the G1 phase arrest was due to direct Cdk4 inhibition and likely due to decreased levels of cyclin D1 [31]. We found by CETSA, however, that luteolin thermostabilizes Cdk9 in cells. Notably, Cdk9 contains a malleable ATP binding site and a flexible C-terminal tail that is not present in cell cycle Cdks $[32,33]$. Thus, selective inhibition of Cdk9 over other Cdks by certain flavones may result from the malleability of the Cdk9 ATP binding site, as previously suggested in structural and functional studies with Cdk9 inhibitors, such as the flavone-derived compound flavopiridol [34].

The arrangement of the core structure rings and the functional groups of flavonoids has been shown to affect their biological activities. Accordingly, the isoflavones daidzein or genistein did not affect Mcl-1 levels, whereas the flavonol quercetin had relatively minor activity. Polier et al. 2011 demonstrated that certain flavones inhibit Cdk9 activity and downregulate Mcl-1 [35], whereas Echalier et al. 2014 showed that daidzein or genistein induce an 8 -fold lower thermal shift of 
Cdk9 in vitro when compared to the flavone apigenin [36]. These data suggest that anti-Mcl-1 activity of some flavonoids is related their capacity to inhibit Cdk9.

We draw several conclusions from the isolation of luteolin from T. rhombifolia and its inhibition of Cdk9. First, some Canadian prairie plant species produce secondary metabolites that can affect mammalian cells and these chemicals can be isolated by biology-guided fractionation. We report that Thermopsis rhombifolia, a toxic plant, produces sufficient amounts of luteolin that can be detected in cell based assays as an anti-Mcl- 1 . This flavone is widely studied and is reported to affect a multitude of pathways when applied to cells, including toxicity, anti-oxidant, inflammation, and proliferation [37]. The sum of its activities has led to studies suggesting roles in chemopreventive cancer treatments [38]. G1 phase inhibitors are scarce as cell biology tools, and we propose that luteolin can be used as an inexpensive and convenient chemical inhibitor of the cell cycle, when used at relatively low concentrations.

\section{Conclusions}

The cell cycle arrest and anti-Mcl-1 activity in extracts of the prairie plant, Thermopsis rhombifolia, was used to isolate the natural product, luteolin. This molecule inhibits the protein kinase $\mathrm{Cdk} 9$ biochemically and in cells.

\section{List of Abbreviations}

BSA: bovine serum albumin

Cdk9: cyclin dependent kinase

CETSA: cellular thermal shift assay

CPT: camptothecin

CTD: carboxy-terminal domain

DMSO: dimethysulfoxide

DTT: dithiothreitol

EDTA: ethylenediaminetetraacetic acid

h: hours

HPLC: high pressure liquid chromatography

NMR: nuclear magnetic resonance

NT: not treated

RNAPII: RNA polymerase II

STS: staurosporine

UV: ultraviolet

\section{Conflicts of Interest}

Stéphane Bach is a founder and member of the scientific advisory board of SeaBeLife Biotech (Roscoff, France). SeaBeLife Biotech is developing novel therapies for treating liver and kidney acute disorders. The other authors do not have a conflict of interest.

\section{Authors' Contributions}

DT, SMK, BB, SB, StB, MB, IP, FS: collected and analysed data and gave final approval of the version to be published.

JMT, RMG: contributed to study design and planning, assisted with the collection and analysis of data, revised the manuscript critically, gave final approval of the version to be published, agree to be accountable for all aspects of the work in ensuring that questions related to the accuracy or integrity of any part of the work are appropriately investigated and resolved.

\section{Acknowledgements}

We appreciate the help from Mr. Rodrigo Polo, Mrs. Polo, Dr. John Bain, Joanne Golden, and Dr. Cody Lewis, Justin Luu in plant collections and discussions. We thank members of the Cancer Cell and Natural Product Laboratories for valuable discussions.

The authors also thank the Cancéropôle Grand Ouest ("Marines molecules, metabolism and cancer" network), IBiSA (French Infrastructures en sciences du vivant: biologie, santé et agronomie) and Biogenouest (Western France life science and environment core facility network) for supporting the KISSf screening facility (FR2424, CNRS and Sorbonne Université), Roscoff, France.

\section{Funding}

The Prairie to Pharmacy Program was funded by the Canada Foundation of Innovation (CFI), University of Lethbridge, and NSERC Discovery Grants. We thank AGILITY (University of Lethbridge) for support.

\section{References}

[1] Rosenthal G, Berenbaum M. Herbivores: their interactions with secondary plant metabolites: ecological and evolutionary processes. San Diego: Academic Press Inc.; 2012.

[2] Alberta Agriculture and Rural Development (AARD). Poisonous Outdoor Plants. Edmonton, Alberta, Canada; 1995.

[3] Newman DJ, Cragg GM. Natural products as sources of new drugs from 1981 to 2014. J Nat Prod. 2016;79(3): 629-61. https://doi.org/10.1021/acs.jnatprod.5b01055

[4] Swinney DC, Anthony J. How were new medicines discovered? Nature Rev Drug Disc. 2011;10(7):507-19. http://doi.org/10.1038/nrd3480

[5] Moffat JG, Vincent F, Lee JA, Prunotto M. Opportunities and challenges in phenotypic drug discovery: an industry perspective. Nature Rev Drug Disc. 2017;16(8):53143. http://doi.org/10.1038/nrd.2017.111 
[6] Moss EH, Packer JG. Flora of Alberta: A manual of flowering plants, conifers, ferns, and fern allies found growing without cultivation in the province of Alberta, Canada. 2nd ed. Toronto: University of Toronto Press; 1983. $687 \mathrm{p}$.

[7] Bach S, Knockaert M, Reinhardt J, Lozach O, Schmitt S, Baratte B, et al. Roscovitine targets, protein kinases and pyridoxal kinase. J Biol Chem. 2005;280(35):31208-19. http://doi.org/10.1074/jbc.M500806200

[8] Martinez Molina D, Jafari R, Ignatushchenko M, Seki T, Larsson EA, Dan C, et al. Monitoring drug target engagement in cells and tissues using the cellular thermal shift assay. Science. 2013;341(6141):84-7. http://doi. org/10.1126/science.1233606

[9] Jafari R, Almqvist $H$, Axelsson $H$, Ignatushchenko $M$, Lundbäck T, Nordlund P, et al. The cellular thermal shift assay for evaluating drug target interactions in cells. Nat Protoc. 2014;9(9):2100-22. http://doi.org/10.1038/ nprot.2014.138

[10] Kernéis S, Swift LH, Lewis CW, Bruyère C, Oumatab N, Colas $\mathrm{P}$, et al. Natural product extracts of the Canadian prairie plant, Thermopsis rhombifolia, have anti-cancer activity in phenotypic cell based assays. Natural Prod Res. 2015;1342(3):337-48. http://doi.org/10.1080/1478 6419.2014 .979423

[11] Bettayeb K, Baunbaek D, Delehouze C, Loaec N, Hole A], Baumli S, et al. CDK Inhibitors roscovitine and CR8 trigger Mcl-1 down-regulation and apoptotic cell death in neuroblastoma cells. Genes Cancer. 2010;1(4):369-80. http://doi.org/10.1177/1947601910369817

[12] Goldwasser F, Bae I, Valenti M, Torres K, Pommier Y. Topoisomerase I-related parameters and camptothecin activity in the colon carcinoma cell lines from the National Cancer Institute anticancer screen. Cancer Res. 1995;55(10):2116-21.

[13] Huang YT, Hwang JJ, Lee PP, Ke FC, Huang JH, Huang C], et al. Effects of luteolin and quercetin, inhibitors of tyrosine kinase, on cell growth and metastasis-associated properties in A431 cells overexpressing epidermal growth factor receptor. BrJ Pharmacol. 1999;128(5):9991010. http://doi.org/10.1038/sj.bjp.0702879

[14] Nguyen D, Zajac-Kaye M, Rubinstein L, Voeller D, Tomaszewski JE, Kummar S, et al. Poly(ADP-ribose) polymerase inhibition enhances p53-dependent and -independent DNA damage responses induced by DNA damaging agent. Cell Cycle. 2011;10(23):4074-82. http://doi.org/10.4161/cc.10.23.18170

[15] Zhou P, Qian L, Kozopas KM, Craig RW. Mcl-1, a Bcl-2 family member, delays the death of hematopoietic cells under a variety of apoptosis-inducing conditions. Blood. 1997;89(2):630-43. $\quad$ http://doi.org/10.1182/blood. V89.2.630
[16] Bain JF, Flanagan J, Kuijt J. Common Coulee Plants of Southern Alberta. 2nd ed: University of Lethbridge; 2014. $166 \mathrm{p}$.

[17] Keeler RF, Johnson AE, Chase RL. Toxicity of Thermopsis montana in cattle. Cornell Vet. 1986;76(2):115-27.

[18] Spoerke DG, Murphy MM, Wruk KM, Rumack BH. Five cases of Thermopsis poisoning. J Toxicol Clin Toxicol. 1988;26(5-6):397-406.

[19] McGrath-Hill CA, Vicas IM. Case series of Thermopsis exposures. J Toxicol Clin Toxicol. 1997;35(6):659-65.

[20] Keeler R, Baker D. Myopathy in cattle induced by alkaloid extracts from Thermopsis montana, Laburnum anagyroides and a Lupinus sp. J Comp Path. 1990;103(2):169-82. http://doi.org/10.1016/ S0021-9975(08)80173-9

[21] Bali EB, Acik L, Akca G, Sarper M, Elci MP, Avcu F, et al. Antimicrobial activity against periodontopathogenic bacteria, antioxidant and cytotoxic effects of various extracts from endemic Thermopsis turcica. Asian Pacific J Trop Biomed. 2014;4(7):505-14. http://doi. org/10.12980/APJTB.4.2014APJTB-2013-0010

[22] Cigerci IH, Cenkci S, Kargioglu M, Konuk M. Genotoxicity of Thermopsis turcica on Allium cepa L. roots revealed by alkaline comet and random amplified polymorphic DNA assays. Cytotechnology. 2016;68(4):829-38. http:// doi.org/10.1007/s10616-014-9835-8

[23] Grana X, De Luca A, Sang N, Fu Y, Claudio P, Rosenblatt J, et al. PITALRE, a nuclear CDC2-related protein kinase that phosphorylates the retinoblastoma protein in vitro. Proc Natl Acad Sci. 1994;91(9):3834-8. http://doi. org/10.1073/pnas.91.9.3834

[24] Zhu Y, Péery T, Peng J, Ramanathan Y, Marshall N, Marshall T, et al. Transcription elongation factor P-TEFb is required for HIV-1 tat transactivation in vitro. Genes Dev. 1997;11(20):2622-32. http://doi.org/10.1101/ gad.11.20.2622

[25] Itzen F, Greifenberg AK, Bösken CA, Geyer M. Brd4 activates P-TEFb for RNA polymerase II CTD phosphorylation. Nucleic Acids Res. 2014;42(12):7577-90. http://doi. org/10.1093/nar/gku449

[26] Yin T, Lallena MJ, Kreklau EL, Fales KR, Carballares S, Torrres R, et al. A novel CDK9 inhibitor shows potent antitumor efficacy in preclinical hematologic tumor models. Mol Cancer Ther. 2014;13(6):1442-56. http:// doi.org/10.1158/1535-7163.MCT-13-0849

[27] Yang T, Kozopas KM, Craig RW. The intracellular distribution and pattern of expression of $\mathrm{MCl}-1$ overlap with, but are not identical to, those of Bcl-2. J Cell Biol. 1995;128(6):1173-84. http://doi.org/10.1083/ jcb.128.6.1173

[28] Thomas LW, Lam C, Edwards SW. Mcl-1; the molecular regulation of protein function. FEBS Letts. 
2010;584(14):2981-9.

febslet.2010.05.061

http://doi.org/10.1016/j.

[29] Haddad AQ, Venkateswaran V, Viswanathan L, Teahan $\mathrm{S}$, Fleshner NE, Klotz LH. Novel antiproliferative flavonoids induce cell cycle arrest in human prostate cancer cell lines. Prostate Cancer Prostatic Dis. 2006;9(1): 68-76. http://doi.org/10.1038/sj.pcan.4500845

[30] Lim DY, Jeong Y, Tyner AL, Park JH. Induction of cell cycle arrest and apoptosis in HT-29 human colon cancer cells by the dietary compound luteolin. Am J PhysiolGastro Liver Physiol. 2007;292(1):66-75. http://doi. org/10.1152/ajpgi.00248.2006

[31] Ong C-S, Zhou J, Ong C-N, Shen H-M. Luteolin induces G1 arrest in human nasopharyngeal carcinoma cells via the Akt-GSK-3ß-Cyclin D1 pathway. Cancer Lett. 2010;298(2):167-75. http://doi.org/10.1016/j. canlet.2010.07.001

[32] Baumli S, Hole AJ, Wang L-Z, Noble ME, Endicott JA. The CDK9 tail determines the reaction pathway of positive transcription elongation factor $b$. Structure. 2012;20(10):1788-95. http://doi.org/10.1016/j. str.2012.08.011

[33] Baumli S, Hole AJ, Noble ME, EndicottJA. The CDK9 C-helix exhibits conformational plasticity that may explain the selectivity of CAN508. Chem Biol. 2012;7(5):811-6. http://doi.org/10.1021/cb2004516

[34] Hole AJ, Baumli S, Shao H, Shi S, Huang S, Pepper C, et al. Comparative structural and functional studies of 4 (thiazol-5-yl)-2-(phenylamino) pyrimidine-5-carbonitrile CDK9 inhibitors suggest the basis for isotype selectivity. J Med Chem. 2013;56(3):660-70. http://doi.org/10.1021/ jm301495v

[35] Polier G, Ding J, Konkimalla BV, Eick D, Ribeiro N, Kohler $\mathrm{R}$, et al. Wogonin and related natural flavones are inhibitors of CDK9 that induce apoptosis in cancer cells by transcriptional suppression of Mcl-1. Cell Death Dis. 2011;2:e182. http://doi.org/10.1038/cddis.2011.66

[36] Echalier A, Hole AJ, Lolli G, Endicott JA, Noble ME. An inhibitor's-eye view of the ATP-binding site of CDKs in different regulatory states. Chem Biol. 2014;9(6):12516. http://doi.org/10.1021/cb500135f

[37] Lopez-Lazaro M. Distribution and biological activities of the flavonoid luteolin. Mini Rev Med Chem. 2009;9(1):3159. http://doi.org/10.2174/138955709787001712

[38] George VC, Dellaire G, Rupasinghe HPV. Plant flavonoids in cancer chemoprevention: role in genome stability. J Nutr Biochem. 2017;45:1-14. http://doi.org/10.1016/j. jnutbio.2016.11.007 


\section{Article Information}

Managing Editor: Pamela Ovadje

Peer Reviewers: Jonathan Blay, Paul Spagnuolo, Cory Harris

Article Dates: Received Jun 10 20; Accepted Aug 21 20; Published Oct 0820

\section{Citation}

Please cite this article as follows:

Tuescher JM, Tailfeathers D, Kernéis SM, Baratte B, Ruchaud S, Bach S, Batut M, Pouny I, Sautel F, Golsteyn RM. The Canadian Prairie Plant Thermopsis Rhombifolia Contains Luteolin, a Flavone that Inhibits Cyclin Dependent Kinase 9 and Arrest Cells in the G1-Phase of the Cell Cycle. Journal of Natural Health Product Research. 2020 Oct 08: 2(2). https://jnhpresearch.com/index.php/jnhpr/article/view/12

DOI Link: https://doi.org/10.33211/jnhpr.12

\section{Copyright}

(c) Jan M. Tuescher, Deserae Tailfeathers, Sophie M. Kernéis, Blandine Baratte, Sandrine Ruchaud, Stéphane Bach, Muriel Batut, Isabelle Pouny, François Sautel, Roy M. Golsteyn (2020). Published first in the Journal of Natural Health Product Research. This is an open access article distributed under the terms of the Creative Commons Attribution License (https://creativecommons.org/licenses/by/4.0/), which permits unrestricted use, distribution, and reproduction in any medium, provided the original work, first published in the Journal of Natural Health Product Research, an NHP Publications journal, is properly cited. The complete bibliographic information, a link to the original publication on https://www.jnhpresearch.com, as well as this copyright and license information must be included.

Journal of Natural Health Product Research NTTP PT TRTIATIONS

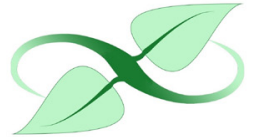

Canadà

Does the safety, efficacy, and quality of natural health products matter to YOU? Submit your research article to the Journal of Natural Health Product Research!

Pre-submission inquiries? Send us an email at editorial.office@jnhpresearch.com Facebook, Twitter and LinkedIn: @NHPPublications 